\title{
The Development Structure of the Merdeka Belajar Curriculum in the Industrial Revolution Era
}

\author{
Indra Maipita ${ }^{1, *}$, Muhammad Bukhori Dalimunthe $^{1}$, Gaffar Hafiz Sagala ${ }^{1}$ \\ ${ }^{1}$ Faculty of Economics, Universitas Negeri Medan, Indonesia \\ ${ }^{*}$ Corresponding Author. Email: imaipita@gmail.com
}

\begin{abstract}
In early 2020, the Ministry of Education and Culture released the Merdeka Belajar policy to innovate higher education learning in Indonesia. Its policy aimed to bridge the gap between business, industry, and higher education. So that higher education institutions can produce greater human resources to earn a competitive advantage. Of course, this policy must be followed up by universities, specifically at the Faculty level, to be crucial as a reference for study programs technically and conceptually for the implementation of Merdeka Belajar. This study aims to develop a curriculum structure that compatible with Merdeka Belajar at the Faculty of Economics, Universitas Negeri Medan. The object of research is updating and implementing the Merdeka Belajar curriculum. The research subjects involved lecturers, faculty functionaries, and practitioners. This study is prospective policy research that uses the Focus Group Discussion technique. Prospective studies are conducted to transform information before a policy action is initiated and implemented. The results of the research are in the form of a curriculum structure containing 1) interpretation of national policies; 2) interpretation of university policies; 3) conceptual basis; 4) study program curriculum structure; 5) course composition; and 6) reference for developing learning tools. This structure is generally used as a reference for other study programs to create Merdeka Belajar designs according to characteristics. For other researchers, this structure can be further developed and tested for its performance in creating a Merdeka Belajar curriculum and its implementation.
\end{abstract}

Keywords: Merdeka Belajar, curriculum development, Indonesia Qualification Framework

\section{INTRODUCTION}

The program policy for the Merdeka Belajar (in English: Freedom Learning) program is a form of autonomous granting of freedom to the campus. It is free from complicated bureaucracies and students' freedom to choose study programs according to the skills they need. To create a campus culture that is autonomous, not bureaucratic, and an innovative learning system based on the interests and guidance of the industrial world. Students are given the freedom to study outside the study program for 3 semesters. This learning experience is expected to provide a learning experience and apprenticeship to face or create jobs in the community.

Currently, most universities have implemented the Indonesian National Qualifications Framework (KKNI) Curriculum since 2018, which is the Merdeka Belajar Policy in line with the KKNI. Merdeka Belajar is a policy that aims to encourage students to master a variety of useful knowledge and skills in the world of work. Meanwhile, the description of qualifications at each level of KKNI is stated as Learning Outcomes (LO), which include aspects of building national identity, mastery of science and technology, the ability to be able to do quality work, as well as the authority and obligations of a person according to the level of qualification. There is the relevance of Merdeka Belajar and KKNI seen in the strategy of achieving Learning Outcomes in each course and graduate of the study program.

The principle of developing a curriculum structure is adjusted to the guidebook for implementing Merdeka Belajar on an independent campus as mandated by the Minister of Education and Culture. These references are then derived into the principles in developing the study program curriculum at the Faculty of Economics, State University of Medan. The principles of developing a curriculum structure which will then become a reference for the study program are relevance, flexibility, continuity, efficiency, and effectiveness.

The Faculty of Economics is an integral part of the Universitas Negeri Medan. It has made efforts to improve the quality of higher education by adopting the Curriculum of Merdeka Belajar, a priority program of the 
Government to create superior human resources. The progress of the 4.0 industrial revolution is the foundation of the program, so the universities must immediately improve the learning activity to aligns it with developing technology. Learning activities contained in the Merdeka Belajar curriculum, namely: 1) internships/industrial practices; 2) project in the village; 3) student exchange; 4) research; 5) entrepreneurship; 6) independent studies/projects; 7) humanitarian projects; 8) teaching in schools [1]. The principles of curriculum development are expected to be used as guidelines for study programs in developing the curriculum to produce a reliable curriculum in achieving learning objectives. The curriculum developed by the study program is also required to bridge the theoretical and practical gap between universities and the government and the industrial world. Thus, universities must ensure the availability of competencies needed by the practical world (government, schools, and industry) in graduates through an Merdeka Belajar curriculum. For this reason, curriculum developers should maintain the following principles during the curriculum structure development process.

Merdeka Belajar policy will certainly affect the curriculum and academic policies at the national, regional, and institutional levels. This policy also has an impact on the methods and strategies of learning in schools and universities. That policy opens opportunities for universities to present more constructive and Merdeka Belajar for students [2]. The Merdeka Belajar policy initiated by the Government has the same direction and goal as Jhon Dewey's progressivism concept. A stream that offers freedom and flexibility to educational institutions to explore students' potential by adjusting their interests and talents [3].

Through the concept of Merdeka Belajar, the learning process focuses on deeper learning in a more real community environment. This approach is expected not only to produce graduates who are knowledgeable but also to have a new mindset that can respond to life's challenges, increase creativity, and innovate in various aspects of life. The learning process must be supported by learning methods that can accommodate the industry's needs. Yamin and Syahrir [4] explain that studying learning methods in the Merdeka Belajar curriculum has an urgent position, so a method is needed to combine face-to-face and virtual learning through the blended learning method. This argument deserves to be supported as one of the appropriate learning methods in implementing a Merdeka Belajar, given the Covid-19 pandemic that has spread to cause online-based learning migration to become a solution. Learning in the midst of a pandemic should be carried out at home or known as Work From Home (WFH) so that it must leave conservative teaching methods [5].

Various challenges and doubts overshadowing this policy mechanism's implementation can be realized in Indonesia, which has disparities in the academic atmosphere, facilities, and infrastructure between universities [6]. Apart from disparity, linking the curriculum of Merdeka Belajar with Indonesia National Qualification Framework (KKNI) is an interesting challenge to study, given the heterogeneous scientific, cultural, atmosphere, and academic activities in the study program. Based on the background and literature review above, the research objective is to develop a curriculum structure that is compatible with the practice of Merdeka Belajar in the era of the industrial revolution.

\section{METHOD}

This research is a policy study. The policy analysis of the study is under prospective analysis. The prospective analysis is conducted to produce and transform information before policy action is initiated and implemented [7]. The prospective analysis was chosen because the curriculum structure is a derivative of the Merdeka Belajar-independent campus policy, which later becomes a reference for academic policy at the faculty and study program levels. This is considered relevant because the prospective analysis is the production and transformation of information before policy action is initiated and implemented [7].

Methodologically, this policy analysis is reviewed descriptively and normatively [7]. Policies will be studied descriptively by examining knowledge about the causes and effects of the Merdeka Belajar policy. The analysis will be conducted based on educational disciplines and associated with the KKNI policy running normatively. These efforts are made to construct curriculum development that has scientific arguments and is relevant in learning practices in higher education.

In operationalizing this prospective study, this study uses exploratory studies [7,8]. The implementation of Merdeka Belajar-independent campuses still requires intact information exploration to predict its implications both theoretically and practically. These efforts are in anticipation of various adjustments at the faculty and study program levels.

Technically, in the first stage, this study was carried out with literature studies to examine theoretical aspects, both from previous studies and previous policies. Furthermore, in the second stage, the research team designed the study program curriculum development structure using the FGD technique. In the third stage, the design of the curriculum development structure is validated by experts. The experts ask to fill the validation instrument as the higher education practitioners represented by top leaders in the academic field, subordinates, lecturers, and education researchers. Furthermore, improvements are made and standardized in the curriculum development structure chart. 


\section{RESULT AND DISCUSSION}

\section{Result of Literature Review}

Referring to the Presidential Regulation No. 8/2012 concerning the Indonesian National Qualifications Framework (KKNI) [9], the current curriculum in higher education has shifted its orientation to be outcomesbased. The Indonesian National Qualifications Framework (KKNI) is a competency qualification ranking framework that can match, equalize, and integrate the education and job training fields and work experience to recognize work competencies following the job structure in various sectors. Indonesian National Qualifications Framework (KKNI) contains an equalization mechanism between the quality of graduates produced by educational programs with the qualifications of the workforce needed. To deal with unemployment problems caused by not acknowledging one's competence, the recognition mechanism for past learning outcomes and recognition of current competencies are needed. Indonesian National Qualifications Framework (KKNI) can be the basis for a strategy to equalize one's qualifications obtained from formal, non-formal, informal education, even from work experience $[10,11]$.

However, the dynamics of learning in Higher Education continues to develop. This development cannot be separated from the acceleration of technological innovation and the business's rapid growth. Responding to these demands, the Ministry of Education and Culture of the Republic of Indonesia (KemdikbudRI) has set a strategy to prepare students to face social, cultural, and workforce changes in this era of rapid progress in science and technology. Kemdikbud views that student competence must be prepared to be more compatible with the needs of the times [1]. Link and match with the world of industry and the world of work and with a rapidly changing future $[1,9,10,11]$. As a result, universities are required to design and implement innovative learning processes to achieve learning outcomes, including aspects of attitude, knowledge, and skills optimally and always relevant. The Ministry of Education and Culture, through its Merdeka Belajar policy, stimulates universities to be more autonomous and flexible in conducting learning to create a learning culture that is innovative, non-restrictive and following the needs of students.

To better understand the urgency of updating the curriculum related to technology and business developments, it is necessary to briefly review these urges, especially after the 4.0 Industrial Revolution (RI). The term RI 4.0 has been declared at the Hannover Fair, Germany, since 2011 [12], but various organizations, including universities, do not immediately respond because they are in a "comfort zone." This is what is known as knowledge stickiness. However, without realizing it, the development of technology and business, which is noted to be driven by the private sector, has exceeded the competencies prepared in Higher Education so that it threatens the competence of higher education graduates to lag behind the need for professional practice in the business and industrial and learning practices in university (which must be the attention of LPTK, See: [1]).

RI 4.0 has indeed disrupted various sectors, causing the birth of various new professions and jobs and threatening the loss of several other occupations and careers [13]. Research by [14] revealed that around 30\% of employment in developed countries would be replaced by robots (automation). About $65 \%$ of future jobs cannot be explained or discovered at this time [15]. Around 75375 million global workers will change professions due to the disruption of RI $4.0[16,17]$. Indonesia is no exception. It is estimated that around $40.8 \%$ of the workforce will be pressured by the impact of automation in the next few years.

With a population of more than 270 million and experiencing a demographic bonus, Indonesia should have the opportunity to grow both in terms of the economy and innovation in the education sector. Various circles predict that Indonesia will have the 7th economic power in the world in 2030 and 4th in the world in 2050 [16]. From a business and entrepreneurial point of view, Indonesia has $3.1 \%$ of the total population's entrepreneurs. This number is relatively small compared to Malaysia, which reached 5\%, Singapore 7\%, Japan $10 \%$, and America $12 \%$. In terms of quality, it is also relatively low.

According to the Global Entrepreneurship Development Institute-GEDI [18], Indonesia's Global Entrepreneurship Index (GEI) still ranks 94th out of 137 countries in 2018, while Thailand is ranked 71st, Malaysia 58, and Singapore 27th. On the other hand, Indonesia has the most excellent digital business potential than other ASEAN member countries, reaching around 25-30 million US dollars. The second position is Thailand, which is approximately 12-15 million US dollars (about half of Indonesia's potential, and the rest are far below). The potential that has not been explored reaches 20-25 million US dollars [19].

The challenge of preparing HR is not an easy matter. Because, in terms of human resources, Indonesia is still experiencing heavy challenges. In 2018, the competitiveness of Indonesian human resources was ranked 45 out of 140 countries. Most of our workforce is still elementary school-educated or below. In the world of education, teachers' average competency score is still around 57 out of 100 . Based on 2018 data, teachers with technology literacy are still around $40 \%$ of the total teachers in this country [20]. This competency gap makes the Faculty of Economic's strategic position as the teacher and professional educators, which is broader and is needed to build future human resources.

The world of education can no longer discuss hard skills, soft skills, intelligence quotient, and emotional quotient. Disruption of technology has disrupted the rhythm of work that has been formed so far. The 
insistence of RI 4.0 requires more than just a study of basic skills but has demanded new literacy mastery. For organizational individuals who master new literacy, disruption actually provides new opportunities. For that, a revolution in ways of thinking and a revolution in learning is needed. The curriculum must be flexible, lecturers and teachers must change the mindset about their duties and functions, must be able to create learning that makes students able to innovate, think about solving problems, generate new ideas that are out of the box, and be able to communicate them, instill a sense of empathy and be able to collaborate across space and time [1].

Higher education has now entered the 21st-century learning era, depending on information technology as an indicator [21]. Not only mastering new literacy, but teachers and lecturers must also be able to instill higherorder thinking skills in students, namely Critical Thinking, Creativity, Collaboration, and Communication [1]. Therefore, as providers of education, tertiary institutions must present and transfer competencies that are "beyond" compared to competency achievements so far. Higher education must carry out computer-mediated heutagogy and be able to exploit it to instill HOTS in students.

Following the Merdeka Learning-Merdeka Campus policy, to bridge the rapid development of technology and business, the collaboration between Universities, industries, and Schools is required. College should be a bridge between theory and practice. Higher education must make industries, government agencies, start-ups, schools, and other institutions as practical laboratories and classrooms. Higher education institutions today must explore knowledge from the world of practice so that teaching materials are truly applied and make alumni able to survive and become innovators in education and business practices. The Faculty of Economics must integrate the three elements that make up the triple-helix, namely universities as educators, government as regulators, and DUDI or schools as practitioners. The synergy of these three elements will generate great and sustainable innovation momentum in Learning in Higher Education.

Faculty Economics, Unimed, carries a double burden, namely producing teachers and business professionals. Thus, the Faculty of Economics, Unimed, has a strategic and broad role in building character, cultured Indonesian human resources, producing competitive products, quality research results, and solving community problems. The policy to carry out curriculum development in this Academic Policy document was updated concerning the National Higher Education Standards (SNPT), KKNI, and Merdeka LearningIndependent Campus. Policies related to the direction of implementing Merdeka Belajar at the university level have been regulated in Regulation of Unimed Rector No. 0362/UN33/PRT/2020 regarding the implementation of Merdeka Belajar. However, given the specificity of the field of study and learning outcomes in study programs within the Faculty of Economics, Unimed needs to design a curriculum development structure at the Faculty level. The curriculum's formulation/development in question is to review the conformity of previously formulated competencies with the needs of business, industry, and schools, referring to developing best practices and an alternative implementation of Merdeka Belajar. This academic policy further requires updating the curriculum for all study programs at the Faculty of Economics, Unimed.

\section{Framework of Curriculum Content}

The curriculum is a learning program design that produces a learning experience aimed at developing student competencies. Referring to Presidential Decree No. 8 of 2012 concerning KKNI, Permendikbud no. 73 of 2013 regarding KKNI in Higher Education, the qualifications resulting from a curriculum in Higher Education must refer to a predetermined KKNI level. The curriculum must also be unique and specific, following the peculiarities of a study program. The curriculum is derived from the Graduate Profile into Graduate Learning Outcomes, Subjects, Subject Learning Outcomes, material/content, models, and media arranged in academic documents and learning tools. These documents and tools are designed to support the achievement of predetermined competencies. Referring to Permendikbud No.3 of 2020 Article 5, Graduate Competency Standards are the minimum criteria for qualifying graduates' abilities, including attitudes, knowledge, and skills stated in the formulation of Graduate Learning outcomes. The skills themselves consist of general and specific skills. Thus, the curriculum developed by the Study Program must be able to achieve aspects of (1) Attitude, (2) Knowledge, (3) General Skills, and (4) Special Skills. Elements of general attitudes and knowledge are standardized, as stipulated in Permendikbud No. 3 of 2020, under the KKNI qualifications. Meanwhile, the study program is responsible for developing aspects of special skills that graduates will have regarding the KKNI qualifications.

The study program curriculum development must be documented in a curriculum document that contains, 1) Vision, mission, and objectives of the study program. This section is essential for developing graduate profiles and graduates' competency standards; 2) Learning Outcomes. This section contains: (a) curriculum development models, (b) generic descriptions of KKNI, (c) qualifications of graduates, (d) specific descriptions and learning outcomes, (e) learning outcomes matrix with study materials, (f) learning outcomes matrix with subjects, (g) specific description matrices, graduate profiles, learning outcomes, and courses; 3) Curriculum structure and course distribution. This section will contain (a) curriculum structure and (b) distribution of courses per semester. 4) Course description. This section 
provides a brief description of all courses, code, number of credits, and prerequisites for following a course.

The curriculum weight that students must take to get a bachelor's degree is 144 credits. Furthermore, the study program curriculum's basic framework, both educational and non-educational, is then constructed and integrated with various courses according to their clusterization. Unimed, this course clustering was developed, referring to the Merdeka Belajar policy released by the Ministry of Education and Culture in 2020. In the Merdeka Belajar program, no. 4, the Ministry of Education and Culture regulates that tertiary institutions give students the right to study a maximum of 3 semesters outside their original study program. Its policy provides opportunities for students to carry out learning activities in other study programs within their home campus, outside their home campus, even real-world such as government, schools, industries, and non-formal institutions in the form of work practices, internships, field practices, and community service. However, this policy must be carefully regulated to ensure learning outcomes, even when students are studying outside their original study program. Therefore, the basic framework of the study program curriculum previously only refers to the Presidential Decree No. 8 of 2012 concerning KKNI, Permendikbud no. 73 of 2013 regarding KKNI, currently being updated with a new reference, namely Permendikbud No. 3 of 2020 and Guide Book of Free Learning-Free Campus. With this update, Unimed rearranged the clustering of Study Program Courses in Unimed through Unimed Rector Regulation No. 0362/UN33/PRT/2020. The clustering policy is described in the next section.

In producing an alternative implementation of Merdeka Belajar that can be chosen by students, study programs must design learning options outside the study program and learning at non-University institutions. In general, study programs must develop alternative learning in other study programs and learn in nonUniversity institutions that students can choose. In principle, the design is carried out so that the students' right to freedom of learning remains linear and supports the achievement of the Learning Outcome of the original study program. In its implementation, the study program must develop and have a manual for the implementation of lectures outside the original study program and in nonUniversity institutions and have standard assessment criteria or assessment conversions. This arrangement can be done by referring to the following principles:

1. The study program needs to deliver the right to study in another study program with a new structure of the curriculum. The origin study program should allocate certain courses that intersect with other study programs. These courses must also support the achievements of the learning outcome of the original study program. Referring to the Merdeka Belajar guidelines [1], lessons that can be taken in other study programs both on and off-campus should be the same or similar courses referring to learning outcome that targeted by the study program (if they have a different name). The reason for providing this option still refers to the achievement of the learning outcome of the original study program and the achievement of the graduate profile. Therefore, to ensure this harmony, the study program must first conduct a curriculum analysis and the availability of courses needed by students in the destination study program. The availability of these courses can only be a few courses if implemented at the Universitas Negeri Medan and must be a package of courses in one whole semester if implemented in other study programs outside Medan State University. The implementation of lectures in other study programs outside the origin University is carried out at least a single full semester with a maximum of 20 credits. Learning activities in other study programs in one university or learning in another study program at different tertiary institutions can be done face-to-face or online. Learning that is carried out online with the provisions of the courses offered must receive recognition from the Ministry of Education and Culture.

2. To grant the right to study at non-University institutions, study programs must prepare a curriculum package in certain semesters that can be taught practically in non-University institutions. The curriculum package is implemented in one full semester and is equivalent to 20 credits. Referring to the Freedom Education Guidelines, study programs can provide learning matters to non-Universities institutions for a maximum of 2 semesters with a maximum credit weight of 40 credits. The granting of these rights is allocated by study programs with rigid mechanisms and procedures so that the targeted learning outcomes are structured and measured. In its implementation, the Study Program firstly must have an MoU and MoA with the School and industries as practical learning locations. Especially for schools, the practice schools recommended by the Ministry of Education and Culture are schools located in the rural area. Furthermore, together with the School and industries, the study program develops a structured practical learning process to build expertise following the learning outcome of the program structure. In its implementation, Study Program can convert learning activities at non-University institutions into two alternatives. First, learning includes aspects of hard skills and soft skills. Each skill makes it possible to get credit credits whose assessment is recognized in the GPA. Second, the learning that is carried out can be converted into relevant subjects referring to the achievement of learning outcomes from the original study program. Examples of applications for these two alternatives can be reviewed in the following table (also available in the Merdeka Belajar-Kampus Merdeka handbook) 


\section{Framework of The Development of Curriculum}

The study program is responsible for designing and developing, organizing, and evaluating the existing curriculum regularly. The current curriculum is relevant to stakeholders' needs and competitive among similar study programs. Curriculum development at the study
Unimed Rector Regulation No. 0362/UN33/PRT/2020 the implementation of Merdeka Belajar for Faculties and Study Programs.

The curriculum must be developed following the level set out in the Indonesia National Qualification Framework, and the proportion and management of

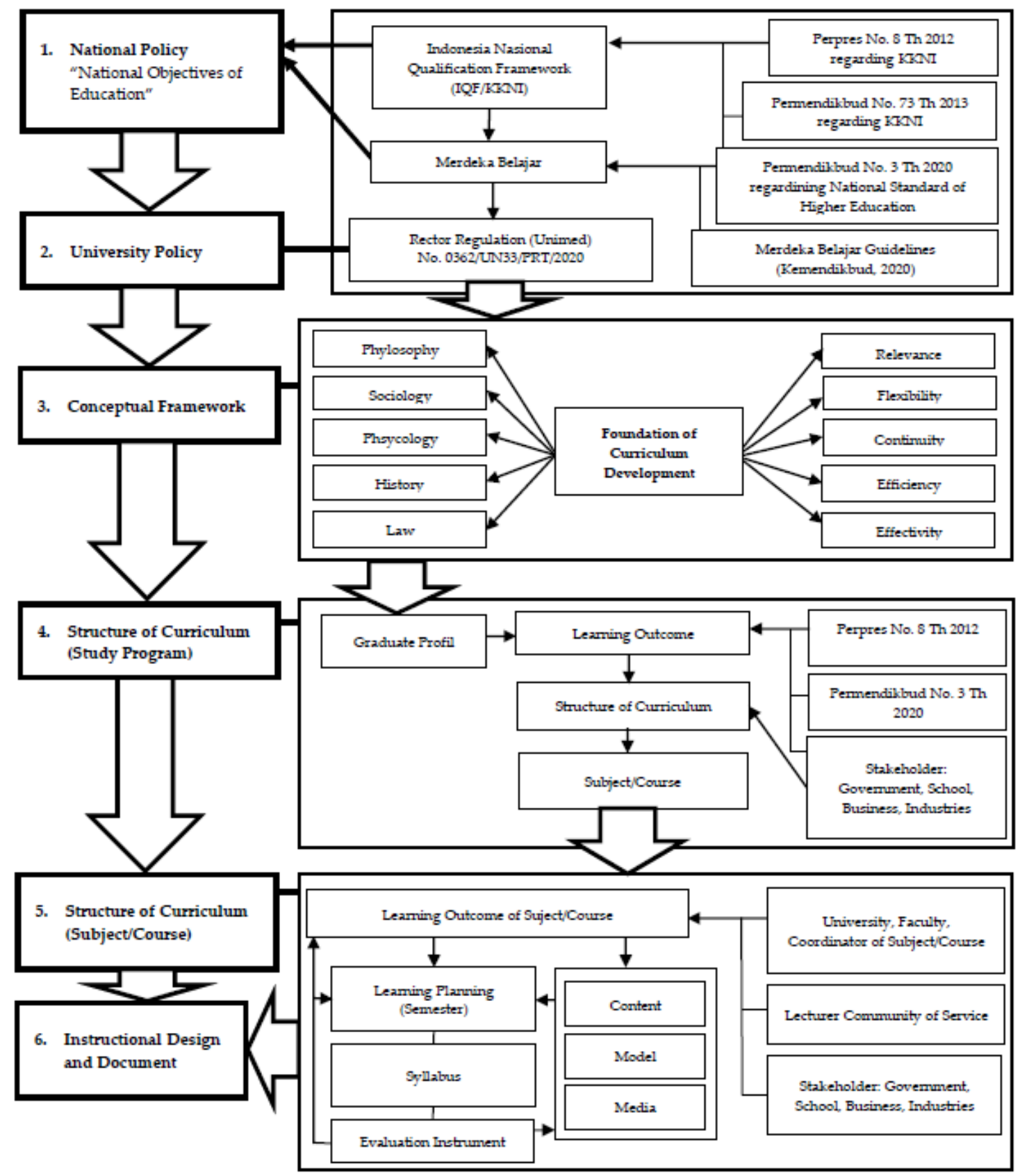

Figure 1. Structure of Merdeka Belajar Curriculum Development, Faculty of Economics, Unimed

program level must comply with Presidential Decree No. 8 of 2012 concerning KKNI, Permendikbud no. 73 of 2013 regarding KKNI in Higher Education, and Permendikbud No. 3 of 2020 concerning the National Higher Education Standards (SN-Dikti). Besides, study programs must also comply with the Guidelines for the Implementation of the Merdeka Belajar Campus released by the Indonesian Ministry of Education and Culture and
Merdeka Belajar refer to the regulations mentioned above. To create the Faculty of Economics curriculum, Unimed, a basic framework is needed to provide direction and signs in developing the curriculum for the study program. It is intended that the developed curriculum is following the vision and mission of study programs, faculties, universities, and following the objectives of national education. Besides, the basic 
framework for developing this curriculum can be used as a reference in evaluation or academic quality assurance efforts in the Faculty of Economics, Unimed. It is because the Faculty of Economics believes that good curriculum development is obtained through systematic development stages. Therefore, the Faculty of Economics designed the curriculum development structure, as presented in Figure 1.

\section{CONCLUSION}

This research is a preliminary study in developing academic policies at the Faculty of Economics, Unimed level, related to implementing the Merdeka Belajar curriculum. The curriculum development structure design developed in this study is based on curriculum development for the study program at the Faculty of Economics, Unimed. This framework is based on the analysis of documents from various sources of legislation, especially Presidential Decree No. 8 of 2012 concerning KKNI, Permendikbud no. 73 of 2013 regarding KKNI, Permendikbud No. 3 of 2020, the guide for the Merdeka-Merdeka Learning Campus, the 2013 Medan State University curriculum development guidebook, the Unimed Chancellor's Regulation No. 0362 / UN33 / PRT / 2020, and previous studies. This framework is expected to be a reference in making systematic changes to the curriculum for study programs or majors in preparing to implement the Merdeka Belajar curriculum.

\section{ACKNOWLEDGMENTS}

The authors would like to thank Universitas Negeri Medan for providing funding support for the policy research grant scheme in 2020.

\section{REFERENCES}

[1] Direktorat Jenderal Pendidikan Tinggi. Buku Panduan Merdeka Belajar - Kampus Merdeka. Jakarta: Kementerian Pendidikan dan Kebudayaan. 2020 .

[2] Sanjaya, W. Pembelajaran Dalam Implementasi Kurikulum Berbasis Kompetensi. Jakarta: Prenada Media Group. 2006.

[3] Mustaghfiroh, S. Konsep "Merdeka Belajar" Perspektif Aliran Progresivisme John Dewey. Jurnal Studi Guru Dan Pembelajaran, 3 (1), 2020, 141-147.. https://doi.org/10.30605/jsgp.3.1.2020.248

[4] Yamin, M., and Syahrir. Pembangunan Pendidikan Merdeka Belajar (Telaah Metode Pembelajaran). Jurnal Ilmiah Mandala Education, 6 (1), 2020, 126136.. http://dx.doi.org/10.36312/jime.v6i1.1121

[5] Saleh, M. Merdeka Belajar di Tengan Pandemi Covid-19. Prosiding Seminar Nasional Hardiknas Belajar dari Covid-19, Vol 1: 51-56. 2020. http://proceedings.ideaspublishing.co.id/index.php/ hardiknas/article/view/8
[6] Arifin, S., dan Muslim, M. Tantangan Implementasi Kebijakan "Merdeka Belajar, Kampus Merdeka" pada Perguruan Tinggi Islam Swasta di Indonesia. Jurnal Pendidikan Islam, 3 (1), 2020, 1-11. https://doi.org/10.32529/al-ilmi.v3i1.589

[7] Dunn, W. N. Pengantar Analisis Kebijakan Publik Edisi Kedua. Yogyakarta: Gajah Mada University. 2003.

[8] Bornman, P. C., Theodorou, N. A., Jeffery, P. C., Marks, I. N., Essel, H. P., Wright, J. P., \& Terblanche, J. Simple closure of perforated duodenal ulcer: a prospective evaluation of a conservative management policy. British Journal of Surgery, 77(1), 1990, 73-75.

[9] Peraturan Presiden nomor 8 tahun 2012 tentang Kerangka Kualifikasi Nasional Indonesia

[10] Peraturan Menteri Pendidikan dan Kebudayaan nomor 3 tahun 2020 tentang Standar Nasional Pendidikan Tinggi.

[11] Peraturan Menteri Pendidikan dan Kebudayaan nomor 73 tahun 2013 tentang Penerapan KKNI Pendidikan Tinggi.

[12] Schwab, K. The fourth industrial revolution. Currency. 2017.

[13] ILO. World Employment and Social Outlook Trends 2017.

[14] PriceWaterhouseCooper. Will robots really steal our jobs? An international analysis of the potential long-term impact of automation. PwC. 2017.

[15] US Bureau of Labor Statistics. Employment Projections. 2019.

[16] McKinsey Global Institute. The Archipelago Economy: Unleashing Indonesia's Potential. 2012.

[17] McKinsey. The Internet of Things: Mapping the Value Beyond the Hype. McKinsey Global Institute. 2015. Retrieved from: https://www.mckinsey.com

[18] Ács, Zoltán J., Szerb, László., Lafuente, Esteban., and Márkus, Gábor. Global Enterpreneur Index. The Global Enterpreneurship and Development Institute (GEDI). 2019.

[20] ISEAS-Yushof Ishak Institute. E-Commerce, Competition \& ASEAN Economic Integration. 2019.

[21] Republika. Kemendikbud: Hanya 40 Persen Guru Siap dengan Teknologi, Republika Online, 04 Desember 2018.

[22] Arends, R. I. Learning to teach: Belajar untuk mengajar. Yogyakarta: Pustaka Pelajar. 2008. 